\title{
MFDICO-PSYCHOLOGIOAL ASSOCIATION OF GREAT BRITAIN AND IRELAND.
}

THE ANNUAL MEETING, 1890.

The Forty-ninth Anvol Mrerrive of the Association will be held on Thursday, July 24th, 1890, at the Royal Asylum, Gartnavel, Glasgow, under the Presidenoy of David YaL Lowlars, M.D., LL.D.

Councir Mietrive, 10 a.m.

Grintad Mreting, 10.30 a.m.

Atrernoon Murting (Presidrnt's Address), 2 p.m.

N.B.-Gartnarel is in the extreme western suburb of Glasgow, but is easily reached by cab, car, or train from Queen Street Station (low level) to Hyndland Station.

\section{A BANDSOME DONATION.-GO THOU AND DO LIKEWISE!}

The study of Psychological Medicine has been lately endowed in a most handsome manner.

Dr. Donald Mackintosh, a Member of the Medico-Psychological Association of long standing, has presented $£ 1,000$ to the University of Glasgow, and a like sum to St. Mungo's College. At the University the sum has been applied

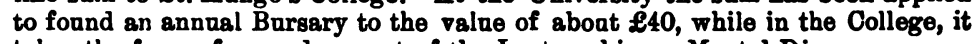
takes the form of an endowment of the Lectureship on Mental Diseases.

These munificent gifts are intended to perpetuate the name and memory of the donor's brother, the late Dr. Alexander Mackintosh, formerly physician saperintendent of the Glasgow Royal Asylum, Gartnavel.

The Mackintosh Psychological Medicine Bursary is conditioned by the following regulations:-

“That the Bursary be awarded annually to matriculated atudents who have attended the Lectures on Insanity in the University of Glasgow.

“That it be awarded after examination by the Professor of Medicine and the Lecturer on Insanity acting jointly, and on the condition that the holder of the Bursary shall, while he continues to hold it, devote special attention to the practical study of insanity to the satisfaction of the Froulty of Medicine."

\section{Correspondence.}

THE LONDON COUNTY COUNCIL AND THE PROPOSED ASYLUM.

\section{To The Ẹditors of "Thx Journal or Mental Bcirevcr.”}

GeNTLEMEN,-I should like to call your attention to the London County Council's Report on an asylum for curable patients. Mr. Brudenell Carter's ill-will against asylum physicians has led him into an error of reasoning. Dr. Sutherland says that four per cent. of the insane are ander medical treatment. Mr. Carter says (p. 20) that assaming 35 per cent. recover, 31 per cent. 
recover without medical treatment. As the admissions (say those under a year's residence) are possibly only a fourth of the total number of patients, and as they are the patients who receive by far the most treatment-a healthy dement not requiring it-this four per cent. of the total may represent 12 per cent. of the admissions. As the admissions are treated as they come in and their health brought up to the normal, it may be that, although only 12 per cent. are treated at one time, in the course of a year all may be treated medicinally. This, of course, is merely arguing as Mr. B. Carter argues. $\Delta_{0}$ a matter of fact, in the asylum in which I reside, and in other places, almost all the admissions are treated by "constructire" medicine on admission, for a month or longer. The Report is 80 offensive that the exposure of an error of this kind may do good. The crudeness of the evidence given is really astonishing.

June 17th.

Yours, otc., R.

\section{Obituary.}

\section{SAMUEL GRIERSON, M.R.C.S., SUPERINTENDENT OF THE ROXBURGH DISTRICT ASYLUM.}

Samuel Grierson died at Edinburgh on the 19th April, 1890, the day before his birthday which would have made him sixty-two years of age. His father was a farmer in Kirkcudbrightshire. He worked his way slowly towards the medical profession, and for about five years was assistant to Dr. Hoffman at Margate, after which he went to study in Edinburgh. Here he found a former friend, Thomas Aitken, another Galloway man, the esteemed Superintendent of the Inverness Asylum. They read and worked together, and kept through life a lasting friendship. After taking the diploma of M.R.C.S. in London, Grierson became assistant in the Southern Counties Asylum in Dumfries for about seven years. Of Dr. Gilchrist, the physician of the Crichton Institution, he always talked in the highest terms. In 1867 Dr. Grierson was appointed Superintendent of the District Asylum for Roxburgh, Berwick, and Selkirkshire. At that time patients were lodged in the buildings connected with Millholme House in Musselburgh; but in 1872 they were shifted to the handsome asylum at Melrose, which was built under Dr. Grierson's direction. One might say that Dr. Grierson's character was a fine blend. He was calm and self-reliant, but sympathetic and very kind-hearted. In manner he was stately, courteous, and somewhat retiring. Though he frequently went to Medical Societies, he scarcely ever spoke, and in company he was always willing to let the rest do the talking. It was only when one or two friends were with him that he would take his share in the conversation. Though habitually grave, he had a fine sense of the ludicrous, and when fairly overcome, his laugh was pleasant to hear. To his patients he was always kindly, attentive, and affable; he would pass hours with them, listening patiently, trying to soothe them, or attend to their little requests. He knew all their cases by heart, which, perhaps, was one of the reasons he disliked taking written notes. He often spoke to them in their own Doric-no one knew better the homely force of the Scottish tongue.

Dr. Grierson's main thought was to comfort and relieve his patients. He never looked approvingly upon attempts to do without locked doors, and was never ashamed to use restraint when he thought his patients' safety and welfare really required it. No one who watched his daily life could fail to see that he was the best and kindest of superintendents; but of self-praise, self-assertion, or affectation of any sort, one would detect no trace. Well-read and skilful in general medicine, Grierson was very skilful in the treatment of the insane, and 